\title{
Sensitivity of Trichomonas vaginalis to metronidazole, tinidazole, and nifuratel in vitro
}

\author{
BENT KORNER AND HAAKON KAALUND JENSEN \\ From the Departments of Clinical Microbiology and Gynaecology, \\ Bispebjerg Hospital, Copenhagen, Denmark
}

\section{Summary}

Prompted by the sensitivity of trichomonads to metronidazole and nifuratel in clinical practice, a study was conducted in 1971-1972 of 63 consecutive strains of Trichomonas vaginalis isolated from women with clinically refractory vaginal discharge. Their susceptibility to metronidazole, tinidazole, and nifuratel was tested, using a serial tube dilution technique. The minimum concentrations which in $48 \mathrm{hrs}$ caused immobilization and lysis of trichomonads cultured in Diamond's medium was assessed.

No differences in drug potency could be determined. The median trichomonistatic and trichomonicidal concentrations were 0.1 and $0.6 \mu \mathrm{g} . / \mathrm{ml}$. respectively when using an inoculum of 10,000 organisms per ml. An inoculum of 100,000 per $\mathrm{ml}$. resulted in inhibitory concentrations of 1.0 and killing concentrations of $3.3 \mu \mathrm{g}$. $/ \mathrm{ml}$. These levels are readily attained in blood and vaginal tissue after oral ingestion of the two imidazole derivatives.

Thus, metronidazole has maintained its efficacy since it was first introduced more than a decade ago. The few therapeutic failures with metronidazole and tinidazole are considered to have been caused by pharmacokinetic deficiencies in the patients, or by re-infection.

\section{Introduction}

In the chemotherapy of vaginal trichomoniasis, metronidazole has won world-wide acceptance since its introduction in 1958, and it has been the drug of choice in Denmark for more than a decade.

Recently, other antitrichomonal agents for oral use have been introduced in Denmark, namely

Received for publication March 24, 1976

Address for reprints: Dr B. Korner, M.D., Ph.D., Department of Clinical Microbiology, Bispebjerg Hospital, DK 2400, Copenhagen, Denmark nifuratel (Polmiror ${ }^{\circledR)}$ in 1967 and tinidazole (Fasigyn $®$ ) in 1972. Both have shown promising results, though nifuratel requires to be given topically as well as by mouth.

The purpose of the present study was to compare the activity of these three compounds in vitro on clinical isolates of Trichomonas vaginalis.

\section{Material and methods}

Over a period of 20 months (1971/1972), 63 consecutive strains of $T$. vaginalis were examined. All strains were recovered from unselected women referred to two gynaecological clinics in Copenhagen City (at Bispebjerg Hospital and St. Joseph's Hospital) because of persistent vaginal discharge and other symptoms and signs of vaginitis; they were, however, not necessarily treatmentrefractory cases. The diagnosis was confirmed at gynaecological examination.

The secretion was collected from the posterior fornix of the vagina by means of charcoal-impregnated cotton-wool swabs. They were stabbed into screw-capped tubes containing culture medium. The swabs were then removed again, and the tightly-closed tubes were taken to the laboratory within $2 \mathrm{hrs}$ in a container kept at 35 to $40^{\circ} \mathrm{C}$.

The tubes were incubated at $35^{\circ} \mathrm{C}$. after a drop of the contents had been transferred to a slide and examined by phase-contrast microscopy.

Various culture media have been advocated for $T$. vaginalis (Taylor and Baker, 1968). Satisfactory results at the Danish State Serum Institute made us choose the medium of Diamond (1957) which supports many organisms per ml. (Capet, 1968; Howes, Lynch, and Kivlin, 1969; Christow, 1971; Nielsen, 1973).

To determine the minimal trichomonistatic and trichomonicidal concentrations (MIC and MCC) of metronidazole, tinidazole, and nifuratel, a standard 2-fold serial dilution test in Diamond's medium was employed, covering a range from 0.06 to $7.5 \mu \mathrm{g} . / \mathrm{ml}$.

The pre-warmed tubes containing the particular antitrichomonal agent and the control tube without agent were inoculated with a $48 \mathrm{hrs}$ ' culture. For the first successive nineteen strains 0.1 to $0.2 \mathrm{ml}$. were used, and for the next 44 strains $2.0 \mathrm{ml}$. To determine the inoculum size, $48 \mathrm{hrs}$ ' cultures of three different trichomonal strains were counted in Bürger-Türk's counting chamber. The counts ranged from 9.6 to $10.4 \times 10^{4}$ per $\mathrm{ml}$. 
After 48 hrs' incubation, the growth rate in the test tubes was estimated by counting the number of visible motile as well as non-motile trichomonads as observed in a standardized 4-ply criss-cross search of a wet mount (phase microscopy; $\times 640$ ). The results were read according to the system shown in Table I.

\section{Results}

Table II shows the typical overall growth sequence of a $T$. vaginalis culture under normal conditions and when an antitrichomonal drug is added in low and high concentrations.

The normal growth curve on the first incubation day consists of a lag phase followed by a logarithmic phase. The next 2 days the culture is full-grown and the conditions are optimal; all cells are highly motile and normal-looking without any appreciable admixture of abnormal or dead cells. From the fourth day onwards the growth curve declines; immobilization and death occur on the fifth day, and all cells are dead-as confirmed by subculture. No noticeable lysis takes place, however, until the following days. This sequence is qualitatively similar to that observed in Oxoid $T$. vaginalis medium No. 2 by Glahn (1973).

Under influence of low (inhibitory) concentrations of a chemotherapeutic agent, the cell motility is reduced during the inital growth phase. On the second day some of the cells die; the microscopic field presents a mixture of motile and nonmotile cells, some of them round, and a few ghost cells. Most of the less sensitive trichomonads survives and produce delayed logarithmic growth density on the fifth day. Hereafter the growth curve slowly falls, ending in complete cell death and lysis around the tenth day. This retarded growth has also been described by Ødegaard (1962).

In presence of high (cidal) concentrations of an antiprotozoal agent, the growth curve is low and brief. The initial growth is accompanied by cell immobilization on the first day; the picture is characterized by a decreased number of organisms, mostly non-motile and lysed cells. Already on the second day almost all cells are dead; at this stage a few immobilized and partly lysed cells remain in the otherwise empty microscopic field. On the third day complete lysis of the culture occurs.

Daily subcultures from the sensitivity test tubes, read after 1 to 3 days' incubation, confirmed that the round immobile cells seen under the microscope were dead. When a mixture of motile and non-motile trichomonads are observed at lower drug concentrations, some survive. Accordingly, the drug concentration needed for complete immobilization almost equals the minimal trichomonicidal concentration-as noted by Ødegaard (1962).

The reproducibility attained was satisfactory. Some of the strains have been kept for up to 3 months in the laboratory by transfers every third day. In eight repeated sensitivity tests on different days the same activity was measured.

The results of the sensitivity studies are recorded in Table III. A total of 63 strains was examined. With the technique employed, no difference could

T A B L E I Evaluation of growth of $\mathrm{T}$. vaginalis and inhibition by drugs

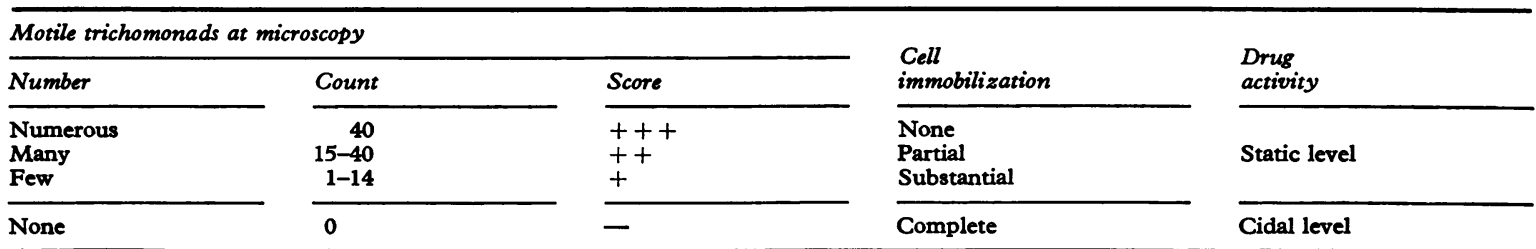

$>40$ per standardized search (see text) means $>5$ per microscopic field, which (according to Nielsen, 1969) corresponds to about $3 \times 10^{6}$ organisms per ml.

T A B L E I I Typical growth phases of T. vaginalis in Diamond's medium (inoculum about 100,000/ml.)

\begin{tabular}{|c|c|c|c|c|c|c|c|}
\hline \multirow[b]{2}{*}{ Day no. } & \multicolumn{3}{|c|}{ Normal culture } & \multicolumn{2}{|c|}{ Trichomonistatic culture } & \multicolumn{2}{|c|}{ Trichomonicidal culture } \\
\hline & Motile cells & Immobile cells & Growth phase & Motile cells & Immobile cells & Motile cells & Immobile cells \\
\hline $\begin{array}{r}1 \\
2 \\
3 \\
4 \\
5 \\
6 \\
7 \\
8 \\
9 \\
10\end{array}$ & $\begin{array}{l}++ \\
+++ \\
+++ \\
++ \\
+ \\
- \\
- \\
-\end{array}$ & $\begin{array}{l}- \\
\overline{-} \\
\overline{+} \\
+++ \\
+++ \\
++ \\
+ \\
-\end{array}$ & $\begin{array}{l}\text { Logarithmic } \\
\text { Stationary } \\
\text { Stationary } \\
\text { Decline } \\
\text { Decline } \\
\text { Cessation }\end{array}$ & $\begin{array}{l}++ \\
+ \\
+ \\
++ \\
+++ \\
++ \\
+ \\
+ \\
+ \\
-\end{array}$ & $\begin{array}{l}\overline{+} \\
\overline{-} \\
\bar{t} \\
+ \\
+ \\
+ \\
-\end{array}$ & $\frac{+}{-}$ & $\begin{array}{l}+ \\
+ \\
-\end{array}$ \\
\hline
\end{tabular}


T A B L E I I I Sensitivity of T. vaginalis in vitro to three drugs (read after 48 hrs' incubation)

\begin{tabular}{|c|c|c|c|c|c|c|}
\hline \multirow[b]{2}{*}{$\begin{array}{l}\text { Inoculum } \\
\text { (T. vaginalis/ml.) }\end{array}$} & \multirow[b]{2}{*}{ Drug } & \multirow[b]{2}{*}{ No. of strains } & \multicolumn{2}{|c|}{ Static concentration $(\mu \mathrm{g} . / \mathrm{ml})}$. & \multicolumn{2}{|c|}{ Cidal concentration ( $\mu \mathrm{g} . / \mathrm{ml}$. ) } \\
\hline & & & Range & Geometric mean & Range & Geometric mean \\
\hline $\begin{array}{l}\text { Small } \\
\text { about } 10,000\end{array}$ & $\begin{array}{l}\text { Metronidazole } \\
\text { Tinidazole } \\
\text { Nifuratel }\end{array}$ & $\begin{array}{l}19 \\
10 \\
19\end{array}$ & $\begin{array}{l}0.06-1.00 \\
0.12-0.25 \\
0.06-0.25\end{array}$ & $\begin{array}{l}0 \cdot 14 \\
0 \cdot 13 \\
0.09\end{array}$ & $\begin{array}{l}0.25-1 \cdot 50 \\
0.50-1 \cdot 50 \\
0 \cdot 12-1 \cdot 50\end{array}$ & $\begin{array}{l}0.59 \\
0.71 \\
0.52\end{array}$ \\
\hline $\begin{array}{l}\text { Large } \\
\text { about } 100,000\end{array}$ & $\begin{array}{l}\text { Metronidazole } \\
\text { Tinidazole } \\
\text { Nifuratel }\end{array}$ & $\begin{array}{l}44 \\
44 \\
32\end{array}$ & $\begin{array}{l}0.50-1.50 \\
0.50-2.25 \\
0.50-1.50\end{array}$ & $\begin{array}{l}0.88 \\
1.08 \\
0.99\end{array}$ & $\begin{array}{l}0.50-7.50 \\
1.50-7.50 \\
1.50-5.00\end{array}$ & $\begin{array}{l}2.79 \\
3.96 \\
3.05\end{array}$ \\
\hline
\end{tabular}

be detected between the potencies of the three drugs, at either static or cidal levels.

The static concentrations for the drugs ranged from 0.09 to $0.14 \mu \mathrm{g} . / \mathrm{ml}$. with the small inoculum (about $10^{4}$ ), and from 0.99 to 1.08 with the large inoculum (about 105). The cidal concentrations ranged from 0.52 to $0.71 \mu \mathrm{g} . / \mathrm{ml}$. with the small inoculum, and from 2.79 to 3.96 with the large inoculum. Thus, a five to ten times higher concentration is necessary for inhibiting or killing a ten times larger inoculum. The ratio between the geometric means are slightly higher for MIC than for MCC.

When the tubes were examined after $24 \mathrm{hrs}$ (instead of $\mathbf{4 8} \mathrm{hrs)}$ the growth was often too sparse for estimation and comparison; this was also noted by Capet (1968).

We observed that the growth of $T$. vaginalis is influenced by the solvent dimethylformamide used for diluting nifuratel; this had not been considered by other investigators (Cavallo, 1963; Scuri and Failla, 1964). In serial dilution tests 0.25 per cent. formamide delays the multiplication, and a slightly higher concentration causes immobilization of part of the cell population. This antitrichomonal activity will certainly influence the results of tests employing higher contents of solvent.

\section{Discussion}

Some clinicians maintain that they have observed an increase in treatment failures with metronidazole, alleging that this may be due to the emergence of metronidazole-resistant strains of $T$. vaginalis in the community. We find no general support in the literature for this assumption. No overall decrease in the therapeutic efficacy of metronidazole has been observed (Keighley, 1971), and no resistant strains have been isolated in cases that did not respond to treatment (McFadzean, Pugh, Squires, and Whelan, 1969). The authors who suggest that resistant strains may have appeared (Arnold, 1966; Aure and Gjønnæss, 1969) did no microbiological tests.
Furthermore, attempts to induce resistance in vitro have failed (Ødegaard, 1962; Watt and Jennison, 1962; Nicol, McFadzean, and Squires, 1966a; Jennison, Stenton, and Watt, 1961; Squires and McFadzean, 1962) when not performed under extreme conditions.

The activity in vitro of the three antitrichomonal agents observed by other investigators are compared with our findings in Table IV. Metronidazole, the oldest of the drugs, has been carefully examined, but few data exist on the two newer drugs. Our results with the nitrodiazoles agree with those experiments in which many strains have been examined. On the other hand, our results with nifuratel differ from those reported by Scuri and Failla (1964) and Bénazet, Lacroix, Godard, Guillaume, and Leroy (1970). The former found MICs ten times smaller than we did, but the latter found MICs ten times greater than our mean. Neither study states the number of strains examined or the size of the inoculum so that the findings cannot be adequately evaluated. A recent study from England (Paredes and Hawkins, 1973) reported results similar to ours.

The correlation between the sensitivity of $T$. vaginalis in vitro and the clinical response to chemotherapy is probably determined by the levels attained in the tissues of the vaginal wall rather than by the levels in the discharge. Metronidazole is present in only very small amounts in vaginal secretions (Paredes and Hawkins, 1973). So far as we know assays of tissue concentrations have not been made, but some data on serum levels are available, although conflicting. Kane, McFadzean, Squires, King, and Nicol (1961) found peak serum levels of 3 to $6 \mu \mathrm{g} . / \mathrm{ml}$. 1 to $2 \mathrm{hrs}$ after the injection of metronidazole $200 \mathrm{mg}$. three times daily for 7 days, whereas Csonka (1971) recorded levels varying between 0.5 and $46 \mu \mathrm{g} . / \mathrm{ml}$. (mean $16 \mu \mathrm{g} . / \mathrm{ml}$.). Nitroimidazole concentrations in human plasma during a course of $250 \mathrm{mg}$. metronidazole or tinidazole three times daily reached 7 to $13 \mu \mathrm{g} . / \mathrm{ml}$. (Taylor, Migliardi, and von Wittenau, 1969). After a single dose of 2 g. metronidazole achieved higher peak concentrations (mean 81 $\mu \mathrm{g} . / \mathrm{ml}$.) than tinidazole $(67 \mu \mathrm{g} . / \mathrm{ml}$.). However, the 
T A B L E I V Activity in vitro of metronidazole, tinidazole, and nifuratel against $\mathrm{T}$. vaginalis

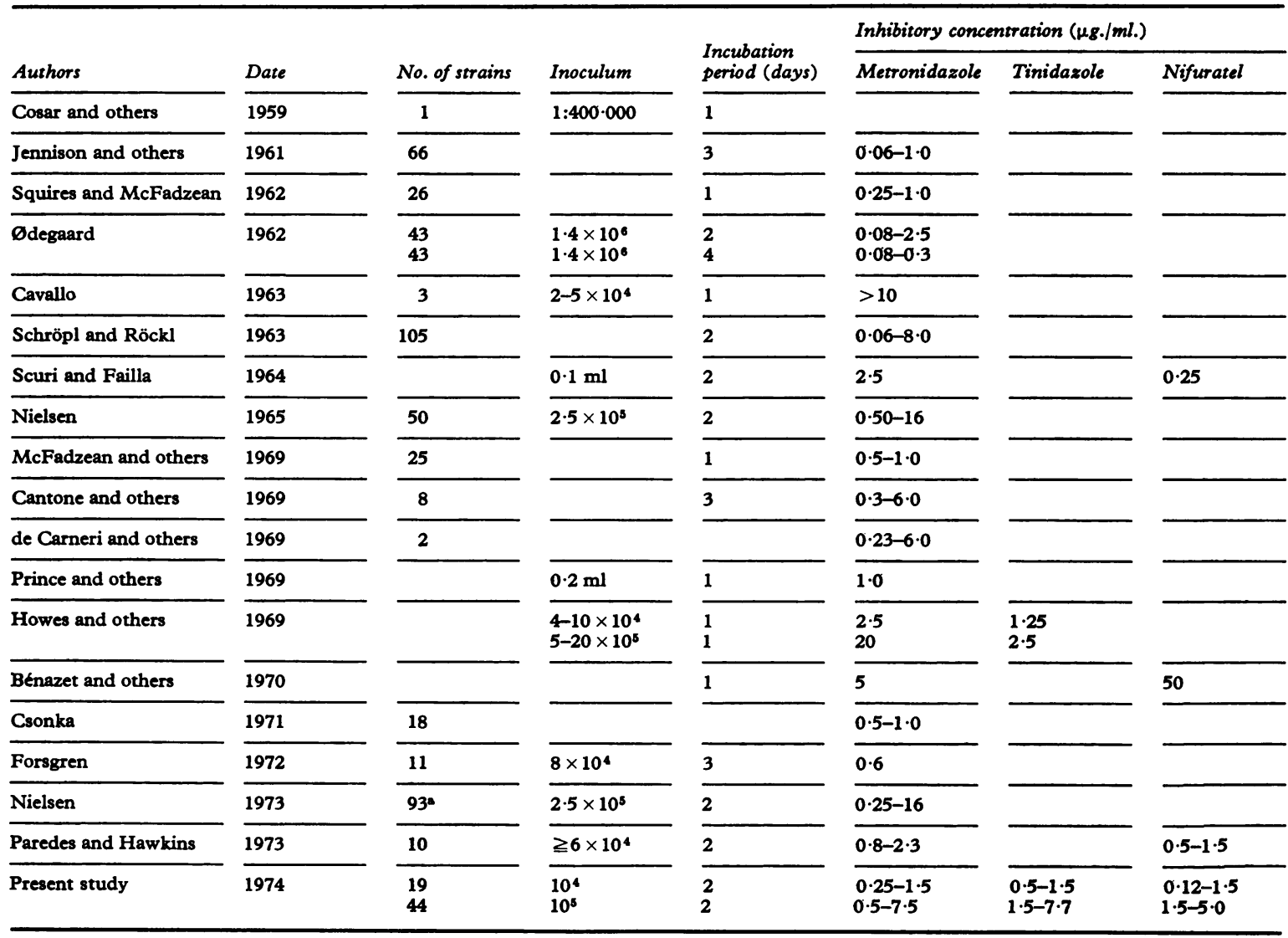

MIC as determined by microscopical examination for absence of motile organisms

sincludes 50 strains from 1965 study

longer serum half-life of tinidazole $(12.5 \mathrm{hrs})$ than of metronidazole $(7.3 \mathrm{hrs})$ led to equal areas-underthe-curve (Wood and Monro, 1975).

No data on the concentrations in humans are available for nifuratel. Rats fed $50 \mathrm{mg}$./kg. (Scuri and Failla, 1964) showed peak levels of 2 to $3 \mu \mathrm{g} . / \mathrm{ml}$. in plasma after $30 \mathrm{~min} ., 3$ to $4 \mu \mathrm{g} . / \mathrm{ml}$. in genital tissue after $2 \mathrm{hrs}$, and 30 to $50 \mu \mathrm{g} . / \mathrm{ml}$. in urine. Since the normal single dose to man is $3 \mathrm{mg}$. $/ \mathbf{k g}$., one would assume that active levels in tissues and secretions are not attained. The manufacturers also state that at lower doses the presence of nifuratel in plasma can not be ascertained by biological tests. Neither human nor animal urine reveal any antitrichomonal activity. Therefore, topical nifuratel application seems essential for its clinical effect.

The results of nifuratel therapy in experimental infections in animals are inconsistent. Scuri and Failla (1964) found that oral nifuratel was active against mouse trichomoniasis, whereas Bénazet and others (1970) claimed that nifuratel was inactive against experimental subcutaneous abscesses in mice. This leaves the question open, but in view of the negligible tissue levels we would rather extrapolate from Bénazet's experiments to clinical conditions. The 50 per cent. curative dose (CD 50) of metronidazole against $T$. vaginalis and $T$. foetus abscesses in mice were 10 and $30 \mathrm{mg} . / \mathrm{kg}$./day (Bénazet and others, 1970). The corresponding activity of metronidazole and tinidazole against $T$. foetus peritonitis (Howes and others, 1969) and orchitis (Tsai and Price, 1973) in mice were about 50 and $10 \mathrm{mg}$./kg./day respectively. These experiments show that tinidazole is two to five times more active than metronidazole in vivo. Howes and others (1969) stated that tinidazole was more potent in vitro (Table IV), and exhibited a more rapid killing effect (it takes metronidazole $48 \mathrm{hrs}$ to produce the same reduction rate as that produced by tinidazole in $8 \mathrm{hrs}$ ). This rather slow effect of metronidazole was also demonstrated by Ødegaard (1962); its maximum effect was first reached after more than 2 days for up to 4 days. 


\section{Conclusion}

The examination of 63 strains of $T$. vaginalis isolated in the years 1971 to 1972 has shown that drugresistant organisms were not present in an unselected group of women suffering from vaginitis. A few strains with the designation 'decreased sensitivity' to metronidazole were isolated from Danish patients in whom treatment had failed (Nielsen, 1973), but the overall susceptibility of these strains did not differ from the normal distribution found by us and by others in a series of patients with $T$. vaginalis (Ødegaard, 1962; Schröpl and Röckl, 1963). In view of these findings we are inclined to rule out in vitro resistance to metronidazole (or tinidazole) as the cause of the therapeutic failures which may be encountered. The causes are more likely to be re-infection, poor intestinal absorption (Kane and others, 1961), or destruction of the drugs (Nicol, Evans, McFadzean, and Squires, 1966b) by intestinal or vaginal bacteria and yeasts.

Our thanks are due to Mrs. Kirsten Larsen for her unfailing technical assistance.

\section{References}

ARNOLD, M. (1966) Ther. Umsch., 23, 356

AURE, J. C., and GJønN\&ss, H. (1969) Acta obstet. gynaec. scand., 48,440

BéNAZET, F., and GuIllaume, L. (1972) Lancet, 1, 597

-, LACROIX, L., GODARD, C., GuIllaUME, L., and LEROY, J-P. (1970) Scand. F. infect. Dis., 2, 139

Bushry, S. R. M., and Copp, F. C. (1955) F. Pharm. Pharmacol., 7, 112

Cantone, A., DE Carneri, I., Emanulli, A., Giraldi, P. N., Logeman, W., Longo, R., Meinardi, G., Monti, G., Nannini, G., Tosolini, G., and Vita, G. (1969) G. Mal. infett., 21, 954

CAPET, R.-G. (1968) Canad. Э. publ. Hlth, 59, 201

de Carneri, I., Achilli, G., Monti, G., and Trane, F. (1969) Lancet, 2, 1308

Cavallo, G. (1963) 'Report on Thyodatil (nifuratel)'. Pisa
Christow, C. P., (1971) Zbl. Bakt. I. Abt. Orig., 217, 540

Cosar, C., Joulou, L., and Bénazet, F. (1959) Ann. Inst. Pasteur, 96, 238

CsonkA, G. W. (1971) Brit. F. vener. Dis., 47, 456

Diamond, L. S. (1957) f. Parasit., 43, 488

ForsGREN, A. (1972) Brit. F. vener. Dis., 48, 205

GlaHN, B. E. (1973) Ugeskr. Lag., 135, 1293

HOWES, H. L. Jr., LYNCH, J. E., and KIVLIN, J. L. (1969) Antimicrob. Agents Chemother., 9, 261

Jeney, E., and ZsolnaI, T. (1969) Zbl. Bakt., I. Abt. Orig., 210, 107

JenNison, R. F., Stenton, P., and WATt, L. (1961) f. clin. Path., 14, 431

Kane, P. O., McFadzean, J. A., Squires, S., King, A. J., and Nicol, C. S. (1961) Brit. F. vener. Dis., 37, 273

KeIGHLEY, E. E. (1971) Brit. med. f., 1, 207

McFadzean, J. A., Pugh, I. M., SQuires, S. L., and WhELAN, J. P. F. (1969) Brit. F. vener. Dis., 45, 161

Nicol, C. S., McFadzean, J. A., and Seuires, S. L. (1966a) Lancet, 1, 1100

- Evans, A. J., McFadzean, J. A., and Squires, S. L. (1966b) Lancet, 2, 441

Nielsen, R. (1965) Proc. fenn.-scand. Ass. Derm., 118

- (1969) Brit. F. vener. Dis., 45, 328

(1973) Ugeskr. Lag., 135, 921 ; Brit. F. vener. Dis., 49, 531

ØDEgAaRd, K. (1962) Nord. Med., 68, 1483

Paredes, F. R., and Hawkins, D. F. (1973) F. Obstet. Gynaec. Brit. Cwlth, 80, 86

Prince, H. N., Grunberg, E., Titsworth, E., and DeLorenzo, W. F. (1969) Appl. Microbiol., 18, 728

SCHRöPL, F., and RöckL, H. (1963) Z. Hyg. Infekt.-Kr. 149,126

ScuRI, R. (1971) Scand. F. infect. Dis., 3, 91

and FaIlla, L. (1964) Farmaco, Ed. sci., 19, 301

Squires, S., and McFadzeAN, J. A. (1962) Brit. F. vener. Dis., 38, 218

TAYLOR, A. E. R., and BAKER, J. R. (1968) 'The Cultivation of Parasites in vitro', p. 98. Blackwell, Oxford

TAYLOR, J. A., jr., Migliardi, J. R., and von WITtenaU, M. S. (1969) Antimicrob. Agents Chemother., 9, 267

TsaI, Y. H., and PRICE, K. E. (1973) Chemotherapy, 18, 348

WatT, L., and Jennison, R. F. (1962) Brit. med. F., 1, 276

Wood, B. A., and MonRo, A. M. (1975) Brit. F. vener. Dis., 51, 51 